\title{
PENGARUH PENDIDIKAN KESEHATAN TENTANG PAP SMEAR TERHADAP PENINGKATAN PENGETAHUAN PADA IBU
}

\author{
The Effect of Health Education About Pap Smear on Improving Knowledge in \\ Mothers
}

\author{
Ni Putu Mirah Yunita Udayani \\ Program Studi Sarjana Kebidanan, STIKES Bina Usada Bali, Badung, Bali, Indonesia \\ Korespondensi : mirahudayani@yahoo.com
}

\begin{abstract}
ABSTRAK
Pap smear merupakan salah satu jenis pemeriksaan skrining, yang mendeteksi secara dini kanker servik yang efektif, sederhana dan murah. Di negara-negara maju, pap smear telah terbukti menurunkan kejadian kanker servik invasif sebesar $46-47 \%$ dan mortalitas kanker servik sebesar $50-60 \%$. Namun di Indonesia tercatat hanya 5\% penduduk wanita Indonesia yang melakukan pemeriksaan pap smear secara rutin. Tujuan penelitian ini adalah untuk mengetahui adanya pengaruh pendidikan kesehatan tentang pap smear terhadap peningkatan pengetahuan ibu di Desa Patemon Kecamatan Seririt Kabupaten Buleleng. Penelitian ini menggunakan desain pra eksperimental dengan pendekatan one group pre test post test. Teknik sampling yang di gunakan adalah purposive sampling dengan melibatkan sebanyak 63 responden. Instrumen yang digunakan dalam penelitian ini adalah kuesioner. Hasil penelitian yang diperoleh dengan menggunakan uji Wilcoxon yakni nilai $Z$ sebesar $-6,542$ dengan $p$ value $=0,00$, dengan menggunakan tingkat kepercayaan $(\alpha)=0,05$. Nilai p value $0,000<\alpha=0,05$, sehingga terdapat pengaruh pendidikan kesehatan tentang pap smear terhadap peningkatan pengetahuan ibu. Wanita dapat melakukan pemeriksaan pap smear sehingga dapat mendeteksi secara dini kanker servik.
\end{abstract}

Kata kunci : penyuluhan, pengetahuan, pap smear

\section{ABSTRACT}

Pap smears are a type of screening examination, which detects early cervical cancer that is effective, simple and inexpensive. In developed countries, pap smears have been shown to reduce the incidence of invasive cervical cancer by $46-47 \%$ and cervical cancer mortality by $50-60 \%$. But in Indonesia only 5\% of Indonesian female population performs routine pap smears. The purpose of this study was to determine the effect of health education about pap smears on increasing maternal knowledge in Patemon Village, Seririt District, Buleleng Regency. This study uses a pre-experimental design with one group pre test post test approach. The sampling technique used was total sampling involving as many as 63 respondents. The instrument used in this study was a questionnaire. The research results obtained using the Wilcoxon test namely $Z$ value of -6.542 with $p$ value $=0.00$, using a level of confidence $(\alpha)=$ 0.05. The value of $p$ value is $0,000<\alpha=0.05$, so that there is an influence of health education about pap-smears on increasing maternal knowledge. a women can have a pap smear so they can detect cervical cancer early.

Keywords : health education, knowledge, pap smear 


\section{PENDAHULUAN}

Pelayanan kebidanan saat ini sudah mulai beralih secara bertahap menuju layanan promotif dan preventif, dimana sebelumnya berfokus pada layanan kuratif dan rehabilitatif (Syarkari \& Anwar, 2017). Pandangan ini sejalan dengan perubahan paradigma bidang kesehatan yaitu dari paradigma sakit menjadi paradigma sehat (Endra, 2010). Pergeseran fokus pelayanan dan perubahan paradigma kesehatan tersebut mengisyaratkan pentingnya melaksanakan upaya promotif dan preventif di berbagai tingkatan, termasuk di tingkat lapisan masyarakat (Syarkari \& Anwar, 2017). Dewasa ini ada beberapa penyakit seperti kanker servik, kanker ovarium, kanker uterus dan kanker payudara yang dapat dihindari atau dikurangi dengan meningkatkan upaya preventif.

Kanker merupakan sebuah penyakit yang diakibat pertumbuhan tidak normal dari sel-sel jaringan tubuh yang sudah menjadi sel kanker (Rohayani, 2010). Kanker servik merupakan penyakit keganasan yang menimbulkan masalah dalam kesehatan wanita terutama di negara berkembang, termasuk di Indonesia. Penderita kanker serviks di Indoenesia pada tahun 2018 mencapai 32.469 jiwa, dengan angka kematian mencapai 18.279 jiwa, serta prevalensi selama 5 tahun pada seluruh kelompok usia mencapai 84.201 jiwa (The Global Cancer Observatory, 2018).

Pada stadium awal, kaker serviks tidak memiliki gejala (Ashtarian, Mirzabeigi, \& Mahmoodi, 2017). Deteksi dini terhadap kanker serviks dapat dilakukan dengan menggunakan pap smear. Skrining menggunakan metode pap smear merupakan metode yang sangat efektif pada kanker serviks (World Health Organization, 2013). Di banyak Negara maju, insiden dan kematian yang diakibatkan kanker serviks setiap tahun mengalami penurunan $50-70 \%$ sejak diterapkannya penggunaan skrining pap smear (Gana et al., 2017). Berdasarkan fakta yang dihimpun dari penelitian terdahulu, diperoleh fenomena faktor yang menghambat seorang wanita melakukan pemeriksaan pap smear. Berdasarkan penelitian yang dilakukan Schiffman \& Solomon (2013), memperoleh gambaran faktor pengetahuan wanita usia subur sangat berpengaruh terhadap perilaku melakukan pemeriksaan pap smear.

Studi pendahuluan yang peneliti lakukan di Desa Patemon Kecamatan Seririt Kabupaten Buleleng dengan menggunakan metode wawancara didapatkan, dari $10 \mathrm{ibu}$ yang di wawancara 8 diantaranya belum mengetahui tentang pemeriksaan pap smear dan sedikitnya informasi yang diterima mengenai kanker serviks dan pap smear. Berdasarkan fenomena tersebut, peneliti memandang perlu dilakukan sebuah upaya intervensi pemberian pendidikan kesehatan menggunakan metode penyuluhan tentang pap smear untuk dapat meningkatkan pengetahuan para ibu.

\section{TUJUAN PENELITIAN}

Penelitian ini bertujuan untuk mengetahui pengaruh pendidikan kesehatan tentang pap smear terhadap peningkatan pengetahuan ibu.

\section{METODE PENELITIAN \\ Desain}

Penelitian ini merupakan jenis pra eksperimen dengan pendekatan one group pre test post test design

\section{Populasi dan Sampel}

Dalam penelitian ini yang merupakan populasi penelitian adalah seluruh ibu-ibu usia reproduktif umur 20-35 tahun yang sudah melakukan hubungan seksual di Desa Patemon Kecamatan Seririt Kabupaten Buleleng. Besar populasi yaitu 153 orang. Berdasarkan rumus Slovin dengan teknik sampling purposive diperoleh jumlah sampel yang akan diteliti yaitu 60 orang dengan kriteria ibu-ibu usia reproduktif usia 20-35 tahun yang sudah pernah melakukan hubungan seksual.

\section{Tempat dan Waktu Penelitian \\ Penelitian ini dilakukan di Desa Patemon Kecamatan Seririt Kabupaten Buleleng, dengan waktu pelaksanaan penelitian 6 bulan serta pemberian intervensi selama 4 minggu,}




\section{Intervensi}

Peneliti memberikan perlakuan berupa pendidikan kesehatan tentang pengertian, manfaat, petunjuk pemeriksaan, waktu yang tepat melakukan pemeriksaan, dan syarat-syarat melakukan pemeriksaan pap smear kepada responden. Dalam memberikan pendidikan kesehatan peneliti menggunakan metode penyuluhan dengan pendekatan ceramah dan presentasi materi. Selanjutnya, peneliti melakukan post test untuk menganalisa perbedaan pengetahuan responden sebelum dan setelah diberikan penyuluhan.

\section{Instrumen dan Prosedur Pengukuran}

Instrumen yang digunakan adalah kuesioner. Kuesioner berisi sederetan pernyataan yang akan diajukan kepada responden dengan skala penelitian ordinal untuk mengetahui pengaruh penyuluhan terhadap peningkatan pengetahuan pada ibuibu tentang pap smear. Skala yang digunakan adalah skala Guttman yaitu dengan memberikan jawaban benar diberikan nilai 1 dan salah diberikan nilai 2 . Hasil uji validitas kuisioner dari 20 item pertanyaan menunjukkan nilai $\alpha<0,005$. Sedangkan nilai reliabilitas kuisioner menunggjukkan nilai $r=0,941$.

\section{Analisa Data}

Analisa data univariat menggunakan analisis variabilitas. Analisa bivariat dilakukan menggunakan wilcoxon sign rank test.

\section{HASIL PENELITIAN}

Berikut ini dijelaskan hasil penelitian berupa karakteristik responden dan hasil uji hipotesis, yaitu sebagai berikut:

\section{Tabel 1}

Tingkat Pengetahuan Ibu $(n=63)$

\begin{tabular}{lcc}
\hline Kategori & $\begin{array}{c}\text { Frekuensi } \\
(\mathrm{F})\end{array}$ & $\begin{array}{c}\text { Persentase } \\
(\%)\end{array}$ \\
\hline Kurang & 0 & 0 \\
Cukup & 27 & 42,8 \\
Baik & 36 & 57,2 \\
\hline Total & 63 & $100 \%$ \\
\hline
\end{tabular}

Dari Tabel 1 menunjukkan tingkat pengetahuan remaja setelah diberikan penyuluhan berada dalam kategori cukup sebanyak 27 orang $(42,8 \%)$ dan kategori baik sebanyak 36 orang $(57,2 \%)$.

\section{Tabel 2}

Pengaruh Pendidikan Kesehatan tentang Pap Smear terhadap Peningkatan Pengetahuan

\begin{tabular}{|c|c|c|c|}
\hline \multicolumn{4}{|c|}{ Pada Ibu $(n=63)$} \\
\hline Varibel & $\mathrm{n}$ & $\mathrm{Z}$ & p-value \\
\hline $\begin{array}{c}\text { pre test-post } \\
\text { test }\end{array}$ & 63 & -6.2898 & 0,000 \\
\hline
\end{tabular}
wilcoxon diperoleh nilai $Z_{\text {hitung }}$ sebesar 6,2898 dengan nilai $p=0,000(\alpha=0,05)$. Berdasarkan $p$-value menunjukkan, ada pengaruh penyuluhan tentang pap smear terhadap peningkatan pengetahuan pada ibuibu tentang pap smear di Desa Patemon Kecamatan Seririt Kabupaten Buleleng.

\section{PEMBAHASAN}

Peningkatkan pengetahuan seseorang dapat dilakukan salah satuanya melalui mendengarkan pendidikan kesehatan. Pengetahuan akan diperoleh melalui proses interaksi dengan lingkungannya (Purbono, Prabawati, \& Tarma, 2015). Pada penelitian ini, setelah dilakukan pengukuran tingkat pengetahuan responden yang mendapat pendidikan kesehatan digolongkan sebagian besar berada dalam kategori baik $(57,2 \%)$. Hasil penelitian ini sejalan dengan penelitian yang dilakukan Gana et al., (2017); Ristraningsih (2017) yang menyebutkan, setelah memperoleh pendidikan kesehatan tingkat pengetahuan responden menjadi baik.

Pengetahuan merupakan domain yang sangat penting untuk terbentuknya tindakan seseorang. Tingkat pengetahuan seseorang berhubungan erat dengan obyek yang pernah dipelajari sebelumnya dengan cara melihat, mendengar dan membaca. Dengan pemberian pendidikan kesehatan melalui penyuluhan diharapkan terjadi peningkatan pengetahuan. Karena pada hakikatnya metode penyuluhan merupakan suatu kegiatan atau usaha untuk menyampaikan pesan kesehatan kepada individu, kelompok 
dan masyarakat sehingga memperoleh pengetahuan tentang kesehatan yang lebih baik yang akhirnya berdampak terhadap perilaku (Notoatmodjo, 2012).

Pendidikan kesehatan yang dilakukan peneliti menggunakan metode penyuluhan dimana pendekatan yang dilakukan adalah dengan pemberian materi secara ceramah dan presentasi materi. Pendekatan ini memiliki kelebihan dimana mudah dilakukan serta mampu terjalinnya komunikasi dua arah, sehingga responden mudah untuk memahami pendidikan kesehatan yang diberikan. informasi yang diberikan menjadi tepat sasaran. Pengetahuan sangat dipengaruhi oleh informasi yang diterima oleh seseorang melalui berbagai sumber. Daryanto (2013) menyebutkan, pemilihan media presentasi yang tepat mampu menarik perhatian responden dalam pelaksanaan pendidikan kesehatan, sehingga informasi mudah diterima. Presentasi dapat disertai dengan teks, dikombinasikan dengan gambar serta anismasi.

Penelitian Ristraningsih (2017) menjelaskan, pemberian pendidikan kesehatan menggunakan pendekatan ceramah dan presentasi memiliki rata-rata nilai pengetahuan yang lebih baik. Presetasi yang ditampilkan dengan gambar-gambar atau animasi yang bergerak tidak terkesan sangat formal. Pemanfaatan media yang tepat akan menjadikan media sebagai sumber pesan kepada penerima pesan, sehingga media dapat menjadi perantara yang erat untuk tersampaikannya informasi dengan baik (Anita, 2010).

\section{KESIMPULAN}

Implikasi

Hasil penelitian menunjukkan bahwa terjadi peningkatan pengetahuan pada ibuibu setelah diberikan pendidikan kesehatan tentang pap smear. Hasil penelitian ini diharapkan dapat menjadi pemacu minat ibu-ibu untuk melakukan pemeriksaan pap smear, sehingga kejadian kanker serviks dapat dicegah atau ditangani sejak dini.

\section{Keterbatasan}

Keterbatasan dalam penelitian ini yaitu pada penggunaan materi instrumen dimana penggunaan bahasa dan istilah medis yang sulit dipahami oleh responden dapat mempengaruhi jawaban dari pada responden.

\section{DAFTAR PUSTAKA}

Anita. (2010). Kesehatan Keproduksi. Yogyakarta: Fitramaya.

Ashtarian, H., Mirzabeigi, E., \& Mahmoodi, E. (2017). Knowledge about Cervical Cancer and Pap Smear and the Factors Influencing the Pap test Screening among Women $\mathrm{O}$ riginal A rticle. Journal International of Community Based Nursing-Midwifery, 5(2), 188195.

Daryanto. (2013). Inovasi Pembelajaran Efektif (Yrama Widy). Bandung.

Endra, F. (2010). Paradigma Sehat. Jurnal Saintika Medika, 6(1), 69-81.

Gana, G. J., Oche, M. O., Ango, J. T., Kaoje, A. U., Awosan, K. J., \& Raji, I. A. (2017). Educational intervention on knowledge of cervical cancer and uptake of Pap smear test among market women in Niger State, Nigeria. Journal of Public Health in Africa, $8(575)$,

111-116. https://doi.org/10.4081/jphia.2017

Notoatmodjo, S. (2012). Promosi Kesehatan dan Perilaku Kesehatan. Jakarta: Rineka Cipta.

Purbono, I. A., Prabawati, M., \& Tarma. (2015). Tingkat Pengetahuan RemajaTentang Kesehatan Reproduksi. Jurnal FamilyEdu, 1(2), 135-149.

Ristraningsih, G. P. (2017). Pengaruh Pendidikan Kesehatan Terhadap Tingkat Pengetahuan Kesehatan Reproduksi Remaja Pada Siswi Kelas VIII di SMP Negeri 28 Semarang. Semarang: Universitas Muhammadiyah Surakarta.

Rohayani, H. (2010). Sistem Pakar Pendeteksi Penyakit Kanker Ganas Yang Menyerang Kaum Wanita. Jurnal Processor, 5(1), 68-81. 
Ni Putu Mirah Yunita Udayani : Pengaruh Pendidikan Kesehatan Tentang Pap Smear Terhadap Peningkatan Pengetahuan Pada Ibu

Schiffman, M., \& Solomon, D. (2013). Cervical-Cancer Screening with Human Papillomavirus and Cytologic Cotesting. The New England Journal of Medicine, 369(24), 2324-2331. https://doi.org/10.1056/NEJMcp12103 79

Syarkari, A., \& Anwar, M. (2017). Gambaran Pengetahuan, Sikap. dan Dukungan Keluarga Oleh Ibu Hamil Terhadap Pelayanan Kebidanan di Wilayah Kerja Puskesmas. J-Kesmas, 3(2), 98-108.

The Global Cancer Observatory. (2018). The Global Cancer Observatory: Indonesia. Geneva. Retrieved from https:/gco.iarc.fr/today/data/factsheets/ populations/360-indonesia-factsheets.pdf

World Health Organization. (2013). WHO guidelines for screening and treatment of precancerous lesions for cervical cancer prevention. South Africa: World Health Organization. 